\title{
Farmers Use of Icts for Marketing Information Outlets in Oyo State, Nigeria
}

\author{
R. A. Oyeyinka ${ }^{1} \&$ R. O. Bello \\ ${ }^{1}$ Department of Agricultural Administration, Federal University of Agriculture, Abeokuta, Nigeria \\ ${ }^{2}$ Department of Agricultural Education, Federal College of Education (Special), Oyo, Nigeria \\ Correspondence: R. A. Oyeyinka, Department of Agricultural Administration, College of Agricultural \\ Management and Rural Development, Federal University of Agriculture, Abeokuta, Ogun State, Nigeria. Tel: \\ 234-803-379-8232. E-mail: akinoye2009@gmail.com
}

Received: August 12, 2013 Accepted: September 11, $2013 \quad$ Online Published: October 15, 2013

doi:10.5539/jas.v5n11p150 URL: http://dx.doi.org/10.5539/jas.v5n11p150

\begin{abstract}
The study examined the use of ICTs for accessing marketing information outlets in Oyo State, Nigeria. A simple random sampling technique was used to select 150 respondents for the study. Data collected were analysed using frequencies counts and percentages to describe the findings while, Chi-square and PPMC were used to test for relationship between the variables in the study hypotheses. The results of the findings showed that majority (70\%) of the sampled respondents were male while (69.3\%) were married with (84\%) of them having a family size of less than five members. Large proportion (59.3\%) of the respondents fall within the ages of 31-50 years, and majority $(74.7 \%)$ of them were rural residence. The results also showed that majority $(81.3 \%)$ of them required information for the sales of their agricultural products. The major sources of agricultural marketing information outlets to the respondents were fellow farmers $(81.3 \%)$, radio $(85.4 \%)$ and GSM $(83 \%)$. The study found that $(61.3 \%)$ of the respondents were in low level category of ICTs users. Inferential statistics indicates that, there were significant relationship between level of use of ICTs for agricultural marketing information and marital status $\left(\chi^{2}=10.46\right.$, $\mathrm{p}>0.05)$ and level of educational attainment $\left(\chi^{2}=16.35, \mathrm{p}>0.05\right)$. However, age $\left(\chi^{2}=5.5, \mathrm{p}<0.05\right)$, sex $\left(\chi^{2}=5.99\right.$, $\mathrm{p}<0.05)$ and family size $\left(\chi^{2}=6.22, \mathrm{p}<0.05\right)$ had no significant relationship with marketing information outlets. PPMC analysis revealed that $\operatorname{radio}(\mathrm{r}=0.28, \mathrm{p}>0.05)$, fellow farmers $(\mathrm{r}=0.19, \mathrm{p}>0.05)$ and $\mathrm{GSM}(\mathrm{r}=0.88, \mathrm{p}>0.05)$ as a source of marketing information were highly significant. The study recommends that government and other stake holders in the information and communication technology industries should endeavour to eliminate the identified barriers to the effective use of ICTs for marketing information outlets in the study area.
\end{abstract}

Keywords: farmers, ICTs, information, marketing, outlets

\section{Introduction}

Agricultural marketing information is relatively a new aspect of agricultural focus, most especially in the developing world. It was in recent times when people in the third world countries discovered that there are a lot of benefits in developing an effective agricultural marketing information structures which will not only promote the agricultural products locally but give it international recognition as well. It is in view of this that the Kenya Agricultural Commodity Exchange came into existence in 1977, to provide market information and services to buyers and sellers not only in Kenya and eastern Africa region alone but the entire world in general. Spore (1998) listed the objective of this unique information to include the following: identifying sellers who are able to guarantee desired products and volumes and finding a buyer without the seller physically bringing the commodity up for sale and a clearing house.

Jonathan et al. (1998), however, identified a defect such as asymmetries of information where parties to transaction have different information about the products offering for sale. This may be in terms of location, time, quantity, quality as well as prize standard. But if all these adequately guided in packaging, the information from the source to the recipient and the essentialness of the message are guaranteed and consequently result to information effectiveness.

At the farm level, one of the greatest challenges facing the local farmers in Nigeria, is the problem of low returns on investment due to lack of post-harvest processing and poor marketing environment. The agricultural market 
environment in the country according to Christoplos (2008) is changing with unprecedented speed and in a very diverse ways. With these changes, it is only a small number of farmers with favourable conditions for production, such as having good access to market information, credit facilities, storage and processing facilities and the like that have been the primary beneficiaries of this new market environment. However the farmers have been largely unable to take advantage of available opportunities due to lack of market information. The few urban distributors according to Adekanye (1988), who are privileged to obtain private market information on good price for their items and the place to get them disposed are the ones that take advantages of the situation and exploit both farmers and consumers. Information and Communication Technologies (ICTs) according to Agboola (2013) could play an important role in addressing these problems of poor market condition in Nigeria. The place of Information and Communication Technologies (ICTs) in the global development is being increasing recognized. This is because the world is rapidly becoming a global village where access to information is faster, quicker and easier than one would ever thought of Arokoyo (2005) defined ICTs as technologies that facilitate communication and the processing and transferring of Information by electronic means to those that need them. This definition encompasses the full range of ICTs from Radio and Television to telephone (Fixed and Mobile), computers and the internet. It can be said that if information on improved marketing outlet are made available to the farmers with effective communication system, their agricultural productivity will be fully enhanced and the cumulative effect will reduce or alleviate poverty in the rural area (Adebo \& Ewuola, 2005). ICTs are veritable tools with which a network of interaction can be stimulated among individual such that they overcome the physical barrier of distance to become integrated into the global knowledge system (Terero \& Braum, 2005). The revolution of ICTs globally has opened greater opportunity for efficient information sharing in the agricultural sector. It has been observed that there has been improvement in agricultural practices over the years in Nigeria and this could be attributed to access to information, improved farming techniques and other needed resources. The used of ICT has potential of bridging the information gap for farmers with respect to innovative practices, government policies, credit facilities and assessing market information outlet. Farmers need information to organize their production activities and such information can help them to make decision, identify market outlets to minimize the risks related to getting the farm products disposing at good prices (Agboola, 2013).

Marketing in agriculture has been defined as the performance of all the business activities involved in the flow of goods and services from the point of initial agricultural production to the ultimate consumers (Bello, 2000; Dittoh \& Adegeye, 1985). In essence, agricultural marketing involves all the stages of operation and movement of commodities from the farmers to the consumers, these includes assemblage of goods, storage, transportation, processing, grading, and financing of such activities.

Agricultural market can be likened to the cradle of exchange between a seller and buyer within a particular period at a specific place. A rural market place for the sale and purchase of agricultural products is an aggregation of effective buyers and sellers who engage in the exchange of goods and services through the forces of demand and supply. The medium through which transaction occurs is money and meeting point for both partner can be conveniently referred to as market place. Agricultural marketing has the potential to make significant contribution to reducing poverty and food insecurity in rural Nigeria. Evidence from case studies, Agboola (2013) and FAO (2003) suggest that in many countries, increased volumes of agricultural exports, by lifting the incomes of farmers have contributed to poverty alleviation and enhance food security in regions where export-oriented agriculture is a primary activity.

The importance of agricultural marketing has not been fully derived due to the fact that considerable effort is yet to be given to it in the national policy on agricultural development. Therefore, the objective of agricultural development should not be just to increase output but to increase net per capital and family income of those that are primarily involved in the agricultural production processes. This was pointed out by Bello (2000) that significant changes in marketing structures have been the corner stone to recent trends towards higher production in developing countries as against the age long stagnation. Sepala et al. (1988) posited that the access of small - scale farmers to marketing channel and farmer's participation in the developing activities should lead to further increase in production. This is turn will stimulate farmers demand for more labour and consequently off - farm employment; since majority of people in developing countries are predominantly farmers their participation in development activities as a result of income generated by those who assumed positions in produce markets that was formerly in the hand of assembly traders, middlemen and produce measurer has improved their well-beings (Bello, 2000).

Agricultural marketing has been constrained by several factors. Some of these include inadequately transport services in rural areas and poor rural feeder roads, poor marketing for agricultural produce in the country, inadequate storage facilities, poor processing facilities and absence of standardization, weighing and scaling equipments for the measurement of products in the market place (Agboola, 2013). 


\subsection{Problem Statement}

Perhaps the most serious problem in Nigeria agricultural marketing system that is relevant to this research work is the one related to marketing information. Agricultural marketing information is scarce in Nigeria because the required data are not usually available and those available are not well managed to generate the required information to support decision making by the producers, consumers, government officials and other market participants. There are no official or organized ways of transmitting price information in Nigerian's agricultural markets, therefore there is no mechanism for coordinating production activities of the millions of farmers, corporate and institution consumers. The paucity of data and information also limit forecasting, planning, farm management and marketing practices (Agboola, 2013).

Generally, observations have shown that farmers have surplus of agricultural; products during harvest. This has resulted in many of the products being wasted on the farm due to lack of awareness of most appropriate places to sell these products. The middlemen capitalize on the ignorance of the farmers and take undue advantage of buying most of these farm produce at cheaper prices directly at the farm gate and later sell to final consumers at an exorbitant price. This has resulted in a general increase in the cost of agricultural products in Oyo State in particular, and Nigeria in general.

In order to alleviate problems such as exploitation of farmers by the middlemen, wastage of agricultural products and resultants increase in price of food products in the market and bridge the gap between farmers and consumers, hence this study was initiated to determine the farmers use of ICTs on agricultural marketing information outlets in Oyo State, Nigeria.

\subsection{Objectives of the Study}

Specifically the study attempted to,

1) describe the personal characteristics of the respondents.

2) determine the sources of ICTs available for agricultural marketing information to respondents.

3) ascertain the respondents access to ICTs component.

4) investigate the farmers level of use of ICTs for marketing information outlets.

5) determine the constraint to the use of ICTs in the study area.

\subsection{Hypotheses of the Study}

Hypotheses of the study stated in null form are as follows:

$\mathrm{Ho}_{1}$ : There is no significant relationship between farmers personal characteristics and level of use of ICTs for agricultural marketing information outlets in the study area.

$\mathrm{Ho}_{2}$ : There is no significant relationship between farmers' sources of agricultural marketing information and level of use of ICTs for marketing outlets.

\section{Materials and Methods}

\subsection{Study Area}

The study was carried out in Oyo State, Nigeria. It lies between latitude $7^{\circ} 23^{\prime} 47^{\prime \prime}$ and $8^{\circ} 00^{\prime} 0^{\prime \prime} \mathrm{N}$, longitude $3^{\circ} 55^{\prime} 0^{\prime \prime}$ $\mathrm{E}$ and $4^{\circ} 00^{\prime} 0^{\prime \prime}$ and covers a total of 27,249 square kilometers of landmass. The total population of the people in the state is estimated at $3,488,789$ as of 2006 census provision figures. The bulk of the population resides in the rural areas of the state. The major occupation of this rural populace is farming. Major food crops grown in the state includes,yam,cassava,maize,okro,cowpea,rice,vegetable,melon,etc. The tree Crops that are majorly grown are cocoa, kola, citrus, cashew and plantain.

The two climatic seasons identified in the study area are dry season which is from November to March and rainy season, which is from April to October. The rainy season is usually interrupted by a short period of drought in late July to early September. Two ecological zones are prominent in the state, the rain forest zone and the savannah ecological zone. The rainfall pattern in the state follows tropical type with an average of annual rainfall of $1000 \mathrm{~mm}-1400 \mathrm{~mm}$ and fairly high temperature. The study was carried out in Ibadan/Ibarapa and Ogbomoso zones of Oyo state agricultural development programme (OYSADEP).

\subsection{Population of the Study}

The population of the Study was residential farmers in Ibadan/Ibarapa zone which falls within rainforest and Ogbomoso zone which falls within the derived savannah of Oyo state. 


\subsection{Sampling Procedure and Sample Size}

For administrative convenience the 33 local government areas in Oyo State was grouped into four (4) zones namely, Ibadan/Ibarapa, Ogbomoso, Oyo and Saki. The field of study covered Ibadan/Ibarapa and Ogbomoso zones which were selected randomly from the four (4) zones. Ogbomoso zones comprises of five local government areas, while Ibadan/Ibarapa areas comprises of 14 local government areas with each local government area representing a block. A block from Ogbomoso and two from Ibadan/Ibarapa were randomly selected for the study. Each block has three cells and a cell contains about 500 residential farmers. A cell was randomly chosen from each block. Ten percent of total farmers in a cell were selected as respondents. This means that 50 farmers per cell were selected; this gave a total of 150 respondents from the three randomly selected cells from the study area. The research instrument contains question items that were used to solicit information along the objectives of the study. Structure questionnaires were used to collect information on the socio-economic and farmer's use of ICTs for marketing information outlets. Both the nominal and interval levels of measurement were adopted. A test re-test reliability coefficient of $r=0.80$ was achieved when the instrument was tested for reliability.

\subsection{Data Analysis}

Data collected were analysed using frequency counts, percentages, chi-squares and Pearson product moment correlation (ppmc).

\section{Results and Discussion}

Table 1. Personal characteristics of respondents, $\mathrm{n}=150$

\begin{tabular}{|c|c|c|}
\hline Variables & Frequency & Percentages \\
\hline \multicolumn{3}{|l|}{ Age in Years } \\
\hline Under 20 years & 22 & 14.7 \\
\hline $21-30$ & 23 & 15.3 \\
\hline $31-40$ & 23 & 15.3 \\
\hline $41-50$ & 66 & 44.0 \\
\hline $51-60$ & 16 & 10.7 \\
\hline \multicolumn{3}{|l|}{ Sex } \\
\hline Male & 105 & 70 \\
\hline Female & 45 & 30 \\
\hline \multicolumn{3}{|l|}{ Marital Status } \\
\hline Single & 38 & 25.3 \\
\hline Married & 104 & 69.3 \\
\hline Widowed & 08 & 5.3 \\
\hline \multicolumn{3}{|l|}{ Educational Attainment } \\
\hline No Formal Education & 62 & 41.3 \\
\hline Completed Primary School & 54 & 36.0 \\
\hline Completed Secondary School & 32 & 21.3 \\
\hline $\begin{array}{l}\text { Completed Tertiary School } \\
\text { Family Size }\end{array}$ & 02 & 1.3 \\
\hline Less than 5 & 126 & 84.0 \\
\hline $5-10$ & 08 & 5.3 \\
\hline Above 10 & 16 & 10.7 \\
\hline \multicolumn{3}{|l|}{ Residence } \\
\hline Rural & 112 & 74.7 \\
\hline Peri- Urban & 23 & 15.3 \\
\hline Urban & 15 & 10.0 \\
\hline
\end{tabular}

Source: Field survey, 2012. 


\subsection{Personal Characteristics of Respondents}

The results on the analysis of the respondents personal characteristics as shown in Table 1 revealed that most $(70 \%)$ of them were male while others $(30 \%)$ were female. The implication of this finding is that farmers in this area of study were dominated by the men. Majority of them (59.3\%) were between the ages of 31-50 years and a large proportion of them $(69.3 \%)$ were married with family size of less than five members $(84 \%)$. The table also indicated that a large proportion (74.7\%) were rural residence, while (15.3\%) and (10\%) were living in peri-urban and urban centres respectively. The implication of this finding is that most of the farmers are rural dwellers and a few that lived in peri-urban and urban practice urban agriculture. The educational background shows that a substantial number of the farmers $(58.7 \%)$ had completed one form of formal education while about two quarter $(41.3 \%)$ of the respondents had no formal education. On a general note however the level of education of the respondents could be described as moderately high, this is likely to influence their level of use of ICTs tools for marketing information outlets in the study area.

\subsection{Farmers' Enterprises Characteristics}

Table 2 shows that (84\%) of the respondents had farming as their primary occupation, (5.3\%) were traders/artisans and $(10.7 \%)$ were civil servants. This implies that farming is the main activity in which many of the respondents were involved. The table 2 also shows, that maize (97.3\%), yam (69.3\%) and cassava (89.3\%) were the most common cultivated of all the arable crops grown by the respondents, in the study area. Regarding the information sought for their enterprises, the results shows that $(81.3 \%)$ required market information, $(52 \%)$ sales information and $(63.3 \%)$ price information, the implication of this finding is that the mostly sought information by the rural entrepreneurs is market information. This is pertinent for them to know the days and location of the markets where their agricultural products can be sold at higher prices. The results also show that, $(66.7 \%)$ of the respondents had between 5 and 20 years of experience in their agricultural enterprises, and (25.3\%) had above 20 years experience while a few (8\%) had less than 5 years experience. The implication of this finding is that, farmers in this area of study are seasoned and experienced farmers in their agronomic practices.

Table 2. Enterprise characteristics of respondents, $n=150$

\begin{tabular}{lll}
\cline { 2 - 2 } Variables & Frequency & Percentages \\
\cline { 2 - 3 } Primary Occupation & 126 & 84.0 \\
Farming & 08 & 5.3 \\
Trading/Artisan & 16 & 10.7 \\
Civil Servant & & \\
$\quad$ Crops Cultivated* & 146 & 97.3 \\
Maize & 86 & 57.3 \\
Melon & 106 & 70.7 \\
Cocoa & 64 & 42.7 \\
Palm Tree & 46 & 30.7 \\
Cowpea & 104 & 69.3 \\
Yam & 134 & 89.3 \\
Cassava & & \\
$\quad$ Natures of Information Required* & 78 & 52 \\
Sales Information & 122 & 81.3 \\
Market Information & 95 & 63.3 \\
Price Information & & \\
Years of Farming Experience & 12 & 8.0 \\
Less than 5 & 38 & 25.3 \\
5-10 & 40 & 26.7 \\
11-15 & 22 & 14.7 \\
16-20 & 38 & 25.3 \\
Above 20 & &
\end{tabular}

Source: Field survey, 2012 .

* Multiple responses. 


\subsection{Sources of Agricultural Marketing Information}

The results in table 3 shows that, the source of agricultural marketing information outlets of respondents were obtained from social sources and well as through ICTs tools. The result revealed that marketing information outlet through fellow farmers was most prominent $(81.3 \%)$ out of the social sources. This implies that the most usually social linkage to the farmers and the markets are fellow farmers. The most used ICTs tools among other sources from which the farmers access market information outlet are Radio (85.4\%) and GSM (83.3\%). This implies that, radio and GSM among other means of disseminating information are the easiest or the mostly used and common in the study area.

Table 3. Sources of Agricultural Marketing Information Outlets, $n=150$

\begin{tabular}{llll}
\hline Sources of Enterprise Information & Always Available & Available & Not Available \\
\hline Social Sources & & & \\
Fellow Farmers & 45.3 & 26.0 & 28.7 \\
Family / Friends & 43.2 & 22.3 & 34.5 \\
Extension Agents & 28 & 36 & 36 \\
ICTs & - & - & \\
Radio & 60.7 & 24.7 & 14.6 \\
Television & 23.3 & 42.0 & 34.7 \\
Newspaper & 12.0 & 34.7 & 53.3 \\
GSM & - & 83.3 & 16.7 \\
Farm Magazine & 4.7 & 15.3 & 80.0 \\
Bulletins & - & 8.0 & 92.0 \\
Posters & 2.7 & 22.7 & 74.7 \\
Internet & - & 18.7 & 81.3 \\
E-mail & - & 13.5 & 86.5 \\
Fax & - & 8.7 & 91.3 \\
\hline
\end{tabular}

Source: Field survey, 2012.

\subsection{Farmers Use of ICTs for Marketing Information}

Table 4 shows the result on various uses of ICTS to access market information outlets (74\%) of the respondents were of the opinion that they used ICT tools to know the market days, (68.7\%) used it to know the market where their products can be sold, while (64\%) used it to know different market locations. The implication of this finding is that ICTs tools such as radio and GSM has improved the farmers' knowledge of agricultural marketing information outlet. On the level of used of ICTs the index created from extent of use of ICTs was used to categorise the respondents into low and high levels based on above and below the mean criterion, in table 5, the results show that, $(61.3 \%)$ of the respondents were categorized as low level users while $(38.7 \%)$ were categorized as high level users. This may be due to mirage of problems confronting the telecommunication industries in the country, for example erratic power supply and the like.

Table 4. Farmers use of ICTs for Marketing Information Outlets, $n=150$

\begin{tabular}{llllll}
\hline ICTs Level of Use & Yes & No & Regularly & Occasionally & Rarely \\
\hline To know Market days & $111(74)$ & $39(26)$ & $66(45)$ & $16(14.7)$ & $29(26)$ \\
To Know market where products can be sold & $103(68.7)$ & $47(31.3)$ & $73(48.7)$ & $38(25.3)$ & $39(26)$ \\
To know market to attend & $104(69.3)$ & $46(30.7)$ & $47(44.7)$ & $31(30.0)$ & $26(25.3)$ \\
To know type of products to sell in the markets & $104(69.3)$ & $46(30.7)$ & $62(59.3)$ & $10(10.0)$ & $32(30.7)$ \\
To know different market locations & $96(64)$ & $54(36)$ & $52(54.7)$ & $13(14.7)$ & $31(30.7)$ \\
\hline
\end{tabular}

Source: Field survey, 2012.

* Multiple responses.

Note: The figures in bracket are percentages. 
Table 5. Farmers Level of the ICTS, $\mathrm{n}=150$

Source: Field survey, 2012.

\begin{tabular}{lll}
\hline Levels & Frequency & Percentages \\
\hline Low & 92 & 61.3 \\
High & 58 & 38.7 \\
Total & 150 & 100 \\
\hline
\end{tabular}

\subsection{Farmers Constraint to Use of ICTs}

The results in table 6 , shows the constraint to the use of ICTs in accessing marketing information outlets in the study area. The areas in which the respondents realized substantial constraints to the use of ICTs were erratic power supply (67.3\%), high cost of maintenance (61.3\%), fluctuating services $(57.3 \%)$, and missed information $(50 \%)$. This implies that erratic power supply is the most realized constraint to use of ICTS in the study area. This is an issue that borders on public policy, which the Nigeria government should endeavour to ameliorate for the benefit of rural and urban farmers.

Table 6. Farmers Constraints to the Use of ICTs, $\mathrm{n}=150$

\begin{tabular}{llll}
\hline Constraints & Severe & Partially Severe & Not Severe \\
\hline Erratic Power Supply & $101(67.3)$ & $35(23.3)$ & $14(10.4)$ \\
Fluctuating Services & $86(57.3)$ & $26(17.3)$ & $38(15.4)$ \\
Repair of Technical Faults & $74(49.3)$ & $42(28.0)$ & $44(22.7)$ \\
Missed Information & $75(50.0)$ & $26(17.3)$ & $50(32.7)$ \\
High Call Tariff & $66(44.0)$ & $56(37.3)$ & $28(18.7)$ \\
High Cost of Maintenance & $92(61.3)$ & $31(20.6)$ & $27(18.1)$ \\
No Network Coverage & $72(48.0)$ & $37(24.6)$ & $41(27.4)$ \\
Inadequate Access to ICTs Tools & $64(42.6)$ & $58(38.6)$ & $28(18.8)$ \\
\hline
\end{tabular}

Source: - Field survey, 2012.

* Multiple responses.

Note: The figures in bracket are percentages.

\subsection{Hypotheses of the Study}

Chi-square analysis between personal characteristics and level of use of ICTs for marketing information outlets. The chi-square analysis in table 7 revealed that there were significant relationship between farmers use of ICTs and marital status $\left(\chi^{2}=10.46, \mathrm{p}<0.05\right)$ and level of education $\left(\chi^{2}=16.35, \mathrm{p}<0.05\right)$, while Age $\left(\chi^{2}=5.5, \mathrm{p}>0.05\right)$, sex $\left(\chi^{2}=5.99, \mathrm{p}>0,05\right)$ and family size $\left(\chi^{2}=6.22, \mathrm{p}>0.05\right)$ among other variables had no significant relationship with farmers use of ICTs for marketing information outlets. The implication of this finding is that,marital status and educational attainment of farmers influence their level of used of ICTs to seek market information in the study area.

Table 7. Chi-Square $\left(\chi^{2}\right)$ analysis of association between personal characteristics and level of use of ICTs for Agricultural Marketing Information Outlets

\begin{tabular}{lccccc}
\hline Variables & $\chi^{2}$ calculated & Df & P & Contingency Coefficient & Decision \\
\hline Age & 5.5 & 4 & 0.835 & 0.21 & NS \\
Sex & 5.99 & 1 & 0.062 & 0.13 & NS \\
Marital Status & 10.46 & 2 & 0.001 & 0.21 & S \\
Level of Education & 16.35 & 3 & 0.001 & 0.23 & S \\
Family Size & 6.22 & 2 & 0.723 & 0.26 & NS \\
\hline
\end{tabular}

Source: - Field survey, 2012. 


\subsection{Correlation Analysis of Sources of Agricultural Marketing Information and Level of Use of ICTs for Marketing Outlets}

In Table 8, Pearson Product Moment Correlation (PPMC), was used to determine the relationship among sources of agricultural marketing information and level of use of ICTs for marketing outlets at 0.05 level of significant. Each co-efficient generated represents the relative combination of its associated variables to that of farmers use of ICTs for marketing information outlets. This implies that the higher the magnitude of the co-efficient, the more important the corresponding variables. The results shows that, there were significant relationship between these information sources, radio $(r=0.28, p<0.05)$, fellow farmers $(r=0.19, p<0.05)$, and GSM $(r=0.38, p<0.05)$ and level of ICTs used for marketing information outlets. However, extension agents $(r=0.02, p>0.05)$, television $(\mathrm{r}=0.07, \mathrm{p}>0.05)$ and internet $(\mathrm{r}=0.03, \mathrm{p}>0.05)$ among other sources of information had no significant relationship with the level of use of ICTs for marketing information outlets. This implies that the frequencies used of radio, GSM and contact with fellow farmers increased the awareness of agricultural marketing outlets which assisted the respondentsto know market locations where their agricultural products can be sold at higher prices in the study area.

Table 8. Relationship between selected sources of agricultural marketing information and level of use of ICTs for marketing outlets

\begin{tabular}{lcccc}
\hline Sources of Agric Marketing Information & No of Cases & Coefficient Correlation (R) & P - Value & Remark \\
\hline Extension Agents & 150 & 0.0213 & 0.77 & NS \\
Radio & 150 & 0.2775 & 0.001 & $\mathrm{~S}$ \\
Television & 150 & 0.0075 & 0.93 & NS \\
Newspaper & 150 & 0.1084 & 0.19 & NS \\
Fellow Farmers & 150 & 0.1910 & 0.019 & $\mathrm{~S}$ \\
GSM & 150 & 0.3772 & 0.001 & $\mathrm{~S}$ \\
Bulletin & 150 & 0.0698 & 0.40 & $\mathrm{NS}$ \\
Posters & 150 & 0.0877 & 0.29 & $\mathrm{NS}$ \\
Internet & 150 & 0.0285 & 0.75 & NS \\
E-mail & 150 & 0.0212 & 0.80 & NS \\
Fax & 150 & 0.0074 & 0.91 & NS \\
\hline
\end{tabular}

Source: Field survey, 2012.

\section{Conclusions and Recommendations}

\subsection{Conclusion}

Based on the findings of the study, majority of the respondents had farming as their primary occupation. Market and price information are mostly sought information by the farmers, Radio and GSM are the mostly used ICTs to access market information. The study also established that majority of the respondents' falls within low users of ICTs tools and the reason behind this may be connected with some of the constraint identified by them as barrier to the effective use of ICTs for marketing information outlets.

\subsection{Recommendations}

Based on the findings of the study, the following recommendations were suggested.

1) Government should endeavour to tackle the problem of erratic power supply to facilitate the use of ICTs tools for marketing information outlets.

2) Government should make ICTs infrastructural to be part of the National infrastructural development, so that the problem affecting the information and communications technology (ICTs) can be ameliorated.

3) The National Communication Commission (NCC) as a regulatory body should ensure that the GSM service providers act within the ambit of the law by not charging exorbitant tariffs on consumers. 


\section{References}

Adebo, G. M., \& Ewuola, S. O. (2005). Impact of Micro Credit and Effective Communication System on Income of Women in Ondo and Ekiti State, Nigeria. Journal of Agricultural Extension, 8, 158.

Adekanye, T. (1988). The Markets for Food Stuffs in Western Nigeria. In T. O. Adekanye (Eds.), Readings in Agricultural Marketing. Nigeria: Lagos, Longman.

Agboola, A. F. (2013). From Indigenous Knowledge System to Agricultural Marketing: Case Study of Traditional Rural Markets in Osun State, Nigeria. In D. O. Torimiro, A. A. Eludire, \& S. K. Subair (Eds.), Proceedings of the International Stakeholders Meeting on E-Agriculture for Productivity and Poverty Alleviation in Africa (pp. 217-219). Held in the Center for In-service and Continued Education, Botswana College of Agriculture, Gaborone, Botswana.

Arokoyo. (2005). ICTs Application in Agricultural Extension Delivery. In S. F. Adedoyin (Ed.), Journal of Agricultural Extension in Nigeria (pp. 245-250). Published by Agricultural Extension Society to Nigeria (AESON).

Bello, R. O. (2000). Effect of Oyinladun Radio Programme on Farmers Awareness of Marketing Outlets in Oyo State, Nigeria. M.Sc. Dissertation, Department of Agriculture Extension and Rural Development. University of Ibadan, Ibadan.

Christoplos, I. (2008). Agricultural Advisory Services and the Market. Overseas Development Institute. National Resource Perspectives.

Dittoh, J. S., \& Adegeye, A. J. (1985). Essential of Agricultural Economics (pp. 164-166). Nigeria: Ibadan Impact Publication.

F.A.O. (2003). Socio-Economic Analysis and Policy Implications of the Roles of Agriculture in Developing Countries. FAO Research Programme Summary Report. Rome. FAO.

Jonathan, B., Stephen, A., Alex, D., \& Stephen, J. (1998). Financing the Future: Options for Agricultural Research and Extension in Sub-Sahara Africa. Oxford Policy Management, Ibadan P2.

Sepala, A. C., Gamage, K. D., \& Senakaarachi, R. B. (1988). Productivity and Employment Implication of Small Scale Farming (pp. 107-109). Sri-Lanka. Agrarian Research and Training Institute, Colombo.

Spore. (1998). Marketing Information. The Case of KACE CTA Information for Agricultural Development in ACP Countries CTA, Wageningen No 78 p16.

Yekinni, T. O. (2011). Contribution of Information and Communication Technologies to Enterprises of Rural Dwellers. The Nigeria Journal of Rural Extension and Development, 5, 7-12.

\section{Copyrights}

Copyright for this article is retained by the author(s), with first publication rights granted to the journal.

This is an open-access article distributed under the terms and conditions of the Creative Commons Attribution license (http://creativecommons.org/licenses/by/3.0/). 